\title{
Legal Assurance Analysis in Disputes Settlement of Rights Transfer to Land Due to Waqf
}

\author{
Kusuma*) and Achmad Sulchan ${ }^{* *}$ \\ *) Faculty of Law, Universitas Islam Sultan Agung (UNISSULA) Semarang, E-mail: \\ kusuma.rasendriya@gmail.com
}

*) Faculty of Law, Universitas Islam Sultan Agung (UNISSULA) Semarang, E-mail: ach.sulchan@unissula.ac.id

\begin{abstract}
The purpose of this research is to find out and analyze: 1). Implementation of the registration of the transfer of ownership of land due to waqf based on Ministerial Regulation no. 2 of 2017 in Madiun Regency. 2). Obstacles and solutions in the process of registering the transfer of ownership rights to land due to waqf. 3). Legal certainty in the settlement of disputes over the transfer of land due to waqf in Madiun Regency. The approach method in this research is empirical juridical, namely research that focuses on individual or community behavior in relation to the law. The data used are primary and secondary data obtained through interviews and literature study, while the data analysis method is done by qualitative descriptive analysis. The results of the research concluded: 1) Implementation of the registration of transfer of ownership rights to land due to waqf based on Ministerial Regulation no. 2 of 2017 in Madiun Regency, namely for land that has not been certified, the documents are equipped such as the Waqf Pledge Deed, photocopy of ID card/KK, photocopy of ID card/right owner identity, certificate of land history, statement of physical possession, power of attorney for application, photocopy of land and building tax, proof of title/proof of ownership, certificate of non-dispute and letter of approval of Nadzir, while for land registration that has been certified, the completeness of the documents required is the Deed of Waqf Pledge, certificate of land rights, photocopy of the applicant's ID card/KK Photocopy of the right owner's ID card/KK, application letter, statement of waqf grace period, Nazhir approval letter, statement of non-disputed land, a statement that the land/building is physically controlled, and proof of SSP/PPH. 2) Obstacles and solutions in the process of registering the transfer of ownership rights to land due to waqf in Madiun Regency, namely there are still some people who are still reluctant to take care of waqf land certificates, because of the assumption that the waqf land certification process requires very expensive costs, the solution made by the government is to carry out socialization and outreach activities to the community 3). Legal certainty in the settlement of disputes over the transfer
\end{abstract}


of land due to waqf is based in Madiun Regency, namely if there is a dispute regarding the property that has been waqf, then the lawsuit is submitted to the competent Religious Court. However, the law allows the settlement of waqf disputes to be settled out of court, as described in Article 62 of Act No. 41 of 2004 concerning Waqf by prioritizing settlement through deliberation.

Keywords: Waqf; Land Registration; Dispute.

\section{Introduction}

Soil has an important role in supporting human life. There are two types of land status known in Indonesia, namely land with the status of state land, and land with the status of land rights. ${ }^{1}$ However, the increasing demand for land leads to land problems. In everyday life, land certificates often become disputes and even go to court. Land disputes can lead to prolonged conflicts between the disputing community members, even to their heirs.

The state as the governing body will always be able to control or direct the management of the functions of the earth, water and space as well as the natural resources contained therein in accordance with existing regulations and policies, namely within the scope of juridical control with a public aspect. ${ }^{2}$ Transfer of control of land rights can occur through legal acts of transfer of land rights. These legal actions include buying and selling, inheritance, grants, waqf, exchange auctions and so on. This transfer of rights causes the transfer of the right to control from one person to another.

One of the legal actions in transferring control of land rights is waqf. According to the Regulation of the Minister of ATR BPN No. 2 of 2017, Waqf is a legal act of Wakif to separate and/or surrender part of his property to be used forever or for a certain period of time in accordance with his interests for the purposes of worship and/or public welfare according to sharia. ${ }^{3}$ Meanwhile, according to Moh. Anwar waqf is holding an item rather than being traded or given or loaned by the owner, to be used as a benefit for certain interests that are permitted by syara' and remain in shape and may be used for the benefit of the specified person (who receives the waqf) or the public. ${ }^{4}$

Land is closely related to worship and other sacred purposes, one of which is land waqf, which in national agrarian law has received attention. With

\footnotetext{
${ }^{1}$ Boedi Harsono, 2007, Hukum Agraria Indonesia: Sejarah Pembentukan Undang-undang Pokok Agraria, Isi dan Pelaksanaannya, ed-11, Djambatan, Jakarta, p.344.

${ }^{2}$ Muhammad Bakri, 2007, Hak Menguasai Tanah Oleh Negara (Paradigma Baru Untuk Reformasi Agraria), Citra Media, Yogyakarta, p. 5

${ }^{3}$ Article 1 Regulation of the Minister of ATR BPN No. 2 of 2017

${ }^{4}$ H. Moh Anwar, 1992, Muamalat, Munakahat, Faaid, dan Janayat, Rineka Cipta, Jakarta, p.494
} 
Government Regulation No. 28 of 1997, waqf of proprietary land is a legal act of a person or legal entity that separates part of his assets in the form of owned land and institutionalizes it forever for the benefit of worship or other public interests in accordance with Islamic teachings. ${ }^{5}$ In Article 3 of the Regulation of the Minister of ATR BPN No. 2 of 2017 Provisions regarding waqf land can be in the form of Ownership Rights or Customary Land that has not been registered, Business Use Rights, Building Use Rights and Use Rights on State Land, Building Use Rights or Use Rights on Land Management Rights or Ownership Rights, Ownership Rights on Flats and State Land Units. ${ }^{6}$

In the event that land with Building Use Rights or Land Use Rights on land with Management Rights or Ownership Rights as referred to in paragraph (1) letter c will be waqf forever, it must first obtain written permission/release from the holders of Management Rights or Ownership Rights. ${ }^{7}$ The condition for the land to be waqf must be Land with Ownership Rights or Land Owned, which in whole or in part must be free from the burden of bonds, guarantees, confiscations and disputes, as referred to in the provisions of Government Regulation no. 28/1977 Article $4 .{ }^{8}$

In order to obtain legal force on the waqf land, a waqf pledge must be made with a deed by the Head of the KUA as the Official Making the Waqf Pledge Deed. The implementation of the waqf pledge, as well as the making of the Waqf Pledge Deed is considered valid, if it is attended and witnessed by at least 2 witnesses, accompanied by letters of proof of land ownership, certificate of village head, certificate of land registration. After the Waqf Pledge Deed is made, then the land waqf registration is carried out to the Regency/City Land Office to obtain a certificate. Waqf land certification is a national program as the responsibility of the government and society. Therefore, to know with certainty the number of waqf lands throughout Indonesia, a complete data collection must be carried out. ${ }^{9}$

Waqf disputes often have the potential in areas that have a wide area. As is the case in Madiun Regency. Madiun Regency has an area of $1,010.86 \mathrm{Km}^{2}$ or $101,086 \mathrm{Ha}$. Madiun Regency is crossed by the Surabaya-Yogyakarta main line, and this district is also crossed by the southern Java railway line. Significant subdistricts are Caruban, Saradan, Dolopo, Dagangan and Balerejo.

\footnotetext{
${ }^{5}$ Adrian Sutedi, 2012, Sertifikat Hak Atas Tanah, Sinar Grafika Jakarta, p.167

${ }^{6}$ Article 3 paragraph (1) Regulation of the Minister of ATR BPN No. 2 of 2017

${ }^{7}$ Ibid. paragraph (3)

${ }^{8}$ Act No. 6 of 1997 concerning Land Registration Procedures Regarding Owned Land Waqf

${ }^{9}$ Adrian Sutedi, op.cit, p. 170
} 
The Madiun City Government socialized the acceleration of waqf land certification. The acceleration is carried out so that all existing waqf lands immediately have certificates. The goal is to be more orderly in land administration. Waqf land that has been certified will be safer because it gets legal protection. With this certificate, land disputes that often arise can be avoided. Dissemination of waqf land certification regulations, procedures and certification processes to the direction and strategy of the certification program by the National Land Agency (BPN) of Madiun Regency. Waqf land certification refers to the Joint Decree (SKB) of the Minister of Religion of the Republic of Indonesia and BPN RI No. 422/2004 concerning Waqf Land Certification, and Regulation of the Minister of ATR BPN No. 2 years 2017.

Based on the background of the problem above, the writer is interested in analyzing the thesis problem about waqf with the title"Analysis of Legal Certainty in Settlement of Disputes on the Transfer of Land Rights Due to Waqf in Madiun Regency. This study seeks to answer the implementation of the registration of transfer of ownership rights to land due to waqf based on Ministerial Regulation no. 2 of 2017 in Madiun Regency, obstacles and solutions in the process of registering the transfer of ownership rights to land due to waqf in Madiun Regency, legal certainty in resolving disputes over transfer of land due to waqf in Madiun Regency.

\section{Research Methods}

The approach method used in this research is empirical juridical. Juridicalempirical namely research that focuses on individual or community behavior in relation to the law. ${ }^{10}$ The specification of the research used is descriptive analytical. Primary data collection was done by interview method. The type of interview used in this study using guided free interviews, is a combination of free and guided interviews. ${ }^{11}$ Secondary data is data obtained from the results of a literature review or a review of various literatures or library materials related to research problems or materials which are often called legal materials. ${ }^{12}$ Analysis of the data used in this study is a qualitative analysis.

\footnotetext{
${ }^{10}$ Soerjono Soekanto dan Sri Mamadji, 2009, Penelitian Hukum Normatif: Suatu Tinjauan Singkat, Raja Grafindo Persada, Jakarta, p.1

11 lbid , p. 84

${ }^{12}$ Mukti Fajar and Yulianto, 2010, Dualisme Penelitian Hukum Normatif dan Empiris, Pustaka Pelajar, Yogyakarta p. 156
} 


\section{Results and Discussion}

\subsection{Implementation of the Registration of Transfer of Ownership of Land Due to Waqf Based on Ministerial Regulation No. 2 of 2017 in Madiun Regency}

Madiun Regency is one of 29 regencies in the East Java Province. Until now, the administrative center of Madiun Regency is still in Madiun City, although now the most progressive regional development is taking place in the Mejayan District. Geographically, Madiun Regency is located at about $7^{\circ} 12^{\prime}$ to $7^{\circ} 48^{\prime} 30$ "South Latitude and $111^{\circ} 25^{\prime} 45$ "to $111^{\circ} 51^{\prime}$ 'East Longitude. The total area is $1,010.86$ $\mathrm{Km} \mathrm{2,} \mathrm{consisting} \mathrm{of} 15$ sub-district administration areas and 206 village/kelurahan administration areas $^{13}$

The extent of agricultural land in Madiun Regency encourages people to donate the land so that it becomes more useful for many people. Each land waqf must be registered with the National Land Agency, in which each region is represented by the Land Office. In Madiun Regency, the Land Office is located at Jl. Dr. Soetomo No.11, Madiun Lor, Kec. Manguharjo, Madiun City.

Post-independence land waqf still gets very high attention until now. The significance is seen in the UUPA Article 49 paragraph 3 which contains special rules in land waqf. Endowment of owned land is protected and regulated by Government Regulation. Meanwhile, there are two government officials who have the authority to administer it, namely the Office of Religious Affairs (KUA) under the Ministry of Religion of the Republic of Indonesia with the main task of guiding procedures, implementing waqf pledges and supervising their management by Nazir; and the National Land Agency (BPN) as the officer for the registration of waqf land as well as its certification. The purpose of waqf land certification has also been regulated in the same law, Article 19 paragraph 1, namely to ensure legal certainty by the government that land registration is carried out throughout the territory of the Republic of Indonesia according to the provisions regulated by government regulations. KHI strengthens these rules through the obligation of waqf in writing in addition to the pronunciation of oral pledges. ${ }^{14}$

The surrender of the land waqf must now be pledged in front of PPAIW and several witnesses to be written in an authentic deed. The land must then be

\footnotetext{
${ }^{13}$ Copyright Document for Madiun Regency 2016 - 2019.

${ }^{14}$ Abror, Khoirul, 2014, Dinamika Perwakafan Dalam Pemikiran Hukum Islam, Peraturan Perundang-Undangan Di Indonesia Dan NegaraNegara Muslim." Al-'Adalah, p. 321-32.
} 
entrusted to Nazir as the manager who has been legalized by the authorized official to be managed in an orderly manner according to the purpose of the waqf. In addition, land that has been waqf must be registered immediately. The next step is to register at the City or Regency BPN where the waqf land is located. The mechanism involving the two government institutions places the waqf land in an official position with legally strong evidence. ${ }^{15}$

The implementation of land registration in Madiun Regency is carried out based on Regulation of the Minister of ATR BPN Number 2 of 2017 concerning Procedures for Registration of Waqf Land at the Ministry of Agrarian and Spatial Planning/National Land Agency. Each application for waqf registration is divided into 2 categories, namely land that has never been certified before (customary land) and land that has been certified.

The procedures for land waqf are:

1. Candidates for Wakif come to the nearest KUA with complete identification and legal documents on the land they own, as well as a statement letter regarding the ownership of the land used as the object of the waqf. Ministerial Regulation of ATR BPN Number 2 of 2017 states that:

Waqf land can be in the form of:

a) Ownership rights or customary land that has not been registered

b) Cultivation rights, building use rights and use rights on state land

c) Building use rights or usufructuary rights on land, management rights or property rights

d) Ownership of the apartment unit

e) State Land

(2) The land as referred to in paragraph (1) may be waqf for a period of time, except for the land as referred to in paragraph (1) letter $\mathrm{c}$ and letter $\mathrm{d}$.

(3) In the event that land with building rights or use rights on land with management rights or property rights as referred to in paragraph (1) letter c will be waqf forever, it must first obtain written permission/release from the holder of management rights or property rights. ${ }^{16}$

\footnotetext{
${ }^{15}$ Urip Santoso, 2007, Kepastian Hukum Wakaf Tanah Hak Milik, Kencana Prenada Media Group, Jakarta, p. 71

${ }^{16}$ Article 3 paragraph (1) - paragraph (3) Regulation of the Minister of ATR BPN Number 2 of 2017 concerning Procedures for Registration of Waqf Land at the Ministry of ATR BPN.
} 
2. The waqif makes the waqf pledge to Nazhir (the waqf property manager) with the witness of the Head of KUA and the beneficiaries. (There are at least two witnesses who must be present in the pledge process. For the record, if the waqf is carried out for an indefinite amount, then the recipient of the waqf does not need to be present.)

3. The Head of KUA makes a Deed of Pledge of Waqf and a letter of ratification.

Before making the Waqf Pledge Deed, the Head of KUA must ensure that the waqf land object is true (based on a certificate from the Village Head).

4. Copies of the deed of pledge were given to Waqif and Nazhir

5. PPAIW on behalf of Nazhir submitted AIW and other documents to the Madiun Regency National Land Office.

For registration of waqf land that has not been certified (customary land), namely:

a) PPAIW on behalf of Nazhir came to the Land Office of Madiun Regency with an Application for Certificate of Land Waqf that was signed and sufficiently stamped and completed the required documents, namely the Deed of Waqf Pledge, Photocopy of KTP/KK, Photocopy of KTP/Identity of Rights Owner, Certificate Land history, physical possession statement, power of attorney application, photocopy of land and building tax, proof of title/proof of ownership, certificate of non-dispute and ratification of Nadzir

b) After complete document requirements, the Land Office will conduct a land inspection. Land inspection is carried out by the land inspection committee in accordance with the object of waqf land. The land inspection was attended by the Head of Sub. Land Rights Registration Section of Madiun Regency Land Office and Sub Section of Facilitation of Procurement and Determination of Government Land Office of Madiun Regency.

c) Furthermore, the chairman of the land inspection committee together with the head of the sub. The Land Rights Registration Section and the Sub-Section for the Facilitation of Procurement and Determination of Land Government of the Madiun Regency Land Office and several staff will conduct a Land Examination Committee Session based on the land requested.

d) After conducting a soil inspection and no obstacles were found on the land, the next step is the measurement carried out by the measuring officer. The surveyor came to the location to confirm the actual land area.

e) The last stage is the issuance of a certificate by the Madiun Regency Land Office to be in the name of Nazhir. 
The application for registration of waqf land originating from customary land and has never been certified at the Madiun Regency Land Office is carried out based on Article 7 of the Regulation of the Minister of ATR BPN No. 2 of 2017, namely:

(1) Waqf land originating from Customary Land is registered as Waqf Land in the name of Nazhir.

(2) The application for registration of Waqf on land parcels as referred to in paragraph (1) shall be accompanied by:

a) application letter;

b) Map of Land Sector/Letter of Measurement;

c) proof of legal land ownership;

d) AIW or APAIW

e) a letter of ratification of the relevant Nazhir from the agency that administers religious affairs at the subdistrict level;

f) a statement from Nazhir/Wakif or a statement from the Village Head/Lurah/community figure that the land is not in dispute, case, confiscated and not guaranteed

(3) In the event that the application for registration as referred to in paragraph (2) has met the requirements in accordance with the provisions of the legislation, the Head of the Land Office issues a decision confirming it as Waqf Land on behalf of Nazhir. ${ }^{17}$

For the process of registering waqf land that has been certified, there are slight differences in the types of documents that must be completed, including:

1) PPAIW on behalf of Nazhir came to the Madiun Regency Land Office to submit an Application for Land Waqf Certification which has been signed and sufficiently stamped, by completing several files of Waqf Pledge Deed, Land Rights Certificate, Photocopy of Applicant's ID Card/Family Card, Photocopy of ID Card/Family Card, Rights Owner, Letter of Application, Statement of Endowment Period of Waqf, Letter of Approval of Nazhir, Declaration of non-disputed land, Declaration of physical possession of land/building and Evidence of SSP/PPH.

2) After complete document requirements, the Madiun Land Office will conduct research and land inspection. For land certificates that have not been split, the rights will be released and the certificate will be split first. In Article 4 of the

${ }^{17}$ Article 7 paragraph (1) - paragraph (3) Regulation of the Minister of ATR BPN Number 2 of 2017 concerning Procedures for Registration of Waqf Land at the Ministry of ATR BPN. 
Regulation of the Minister of ATR BPN No. 2 of 2017 explained aboutcertificate separation, i.e.: ${ }^{18}$

a) In the event that the Waqf Land in the form of Property Rights as referred to in Article 3 paragraph (1) letter a will be waqf only part of the total area, first measurements are made for the separation of the certificate.

b) The separation of certificates as referred to in paragraph (1) is made by AIW or APAIW, and becomes the basis for the issuance of Land Waqf Certificates in the name of Nazhir. ${ }^{19}$

While in Article 5:

In the case of certificates of Hak Guna Usaha, Hak Guna Bangunan and Hak Guna Usaha on State land as referred to in Article 3 paragraph (1) letter $b$, there is a note regarding the permit if it is to be transferred, in order to be able to waqf, it must first obtain permission from the authorized official. ${ }^{20}$

The separation of certificates is carried out to facilitate the process of certifying waqf land that has been certified and to minimize the occurrence of future land disputes.

3) After the land inspection was carried out and no obstacles were found, the last stage was the issuance of a certificate by the Madiun Regency Land Office to be in the name of Nazhir.

\subsection{Obstacles and Solutions in the Process of Registering the Transfer of Property Rights to Land Due to Waqf in Madiun Regency}

Implementation of the registration of the transfer of ownership of land due to waqf based on the Regulation of the Minister of ATR BPN No. 2 of 2017 in Madiun Regency the author did not find any significant obstacles. The obstacle encountered by the author is that there are still some people in Adiun Regency who are still reluctant to take care of waqf land certificates, because of the assumption that the waqf land certification process requires very expensive costs. This is experienced by people who have donated their land, but the status of the land is still customary land (land C) or there is no certificate of ownership. In addition, there is an assumption that the length of time in carrying out

\footnotetext{
${ }^{18}$ Article 4 paragraph (1) and paragraph (2) of the Regulation of the Minister of ATR BPN No. 2 of 2017 concerning Procedures for Registering Waqf Land

${ }^{19}$ Article 4 paragraphs (1) and (2) Regulation of the Minister of ATR BPN Number 2 of 2017 concerning Procedures for Registration of Waqf Land at the Ministry of ATR BPN.

${ }^{20}$ Ibid, Article 5
} 
registration is due to the lack of community knowledge about the importance of legalizing the status of land rights. Based on the research that the author did, In fact, the Office of the Ministry of Religion of Madiun Regency in collaboration with the Land Office and Head of KUA throughout Madiun Regency has provided a solution by increasing socialization to the community which confirms that the cost of waqf land certification is IDR 0 . This is in accordance with government regulation no. 13 of 2010 concerning the types and rates of non-tax state revenues applicable to the National Land Agency.

\subsection{Legal Certainty in Settlement of Disputes on Transfer of Land due to Waqf in Madiun Regency}

The scholars require that waqf assets must be known for certain and not contain disputes. If the nature and amount of the waqf property is not known with certainty, so that in order for the waqf testimony to be declared valid, it must be given certain limitations. ${ }^{21}$ In an increasingly advanced civilization, authentic evidence is needed in every act of transfer of ownership, including in waqf statements from a person, which must be clearly demarcated. This is because in waqf it occurs for a long time, and it is possible that a problem can arise in the clarity of waqf property, even though its status is still waqf. Therefore, all things that strengthen the waqf must include everything that is needed in the conditions for a valid waqf, for example land certificates. ${ }^{22}$

Our country which is based on Pancasila and the 1945 Constitution in carrying out its statehood is based on law, not on mere power. ${ }^{23}$ It means that the state in managing every area of life is based on legal rules and norms. So that the rights and obligations of the community and the state will be protected. In Article 12 the settlement of disputes insofar as they involve land waqf issues, is channeled through the local Religious Court, in accordance with the provisions of the applicable laws and regulations.

If there is a dispute regarding the property that has been waqf, then the lawsuit is submitted to the competent Religious Court. This is in line with the provisions of Act No. 7 of 1989 concerning the Religious Courts, as last amended by Act No. 50 of 2009. Actually, the law allows the settlement of waqf disputes to be settled out of court, as described in Article 62 of Act No. 41 of 2004 concerning Waqf by prioritizing settlement through deliberation and consensus. Settlement through institutions outside the court, such as mediation and arbitration is possible. It

\footnotetext{
${ }^{21}$ Sudirman Hasan, 2011, Wakaf Uang (persepektif Fiqih, Hukum Positif dan Manajemen), UIN Maliki Press, Malang, p. 6

${ }^{22}$ Muhammad Abid, op.cit, p. 251

${ }^{23}$ Explanation of the 1945 Constitution
} 
could be that many were resolved internally by religious leaders because disputes regarding waqf were considered something to be ashamed of.

The settlement of waqf disputes in Madiun Regency as happened in the Mejayan District, the parties prefer to resolve through deliberation. Deliberation is a process of collective bargaining between two or more people to get the best decision. Deliberation is a joint decision-making that has been agreed upon in solving a problem. The way joint decision-making is made if the decision concerns the interests of many people or the wider community. The dispute over the ownership of waqf land is resolved through deliberation between the parties concerned. Here, the one who has a very important role because he has the obligation to manage and be responsible for all matters relating to the waqf land is Nadzir.

According to Nazhir's explanation, the plaintiff (the heirs of the Wakif) also knew that the land was waqf land that his parents had donated to build a mosque. After finally agreeing on a time and place by both parties, the meeting or deliberation begins. This meeting was held at the Nurul Iman Mosque which was established on the waqf land. With deliberation, it is hoped that this waqf land dispute can be resolved amicably. Although the deliberation order has been agreed upon by the parties, the implementation of the deliberation takes a long time, i.e. it takes approximately a week ( 7 days) because there are a lot of negotiations going on. In the ongoing deliberation process. After clarifying the existing problems and equating the understanding, the agenda for the next deliberation is determined. Here, Nazhir arranges an event or agenda for discussion of issues that include time allocation, the schedule for the next meeting that needs to be approved by the parties. So at the first meeting, they discussed what the existing problems looked like, not yet reached the stage of completion.

The parties held a second deliberation using a closed deliberation process, in this case the party who filed the complaint was attended by Sahab's brother and his negotiators while the Nurul Iman Mosque management was attended by Mr. only attended by the parties to the dispute. In deliberation the parties make peace, bargain and develop efforts to reach an agreement. The meeting was carried out smoothly.

The peace agreement that has been signed by the parties is then conveyed to the community, with the aim that the community can be witnesses of this agreement. With the signing of the agreement, this waqf land dispute has ended. Then the task of the Management is that because the waqf land has not been registered, it is necessary to take care of the registration of the waqf land to the local KUA. Land that is waqf for the benefit of the people and the general public, 
then automatically the land rights change to God's property, not to individuals anymore.

This registration of waqf land is very important, both in terms of legal order and in terms of administration of land control and use in accordance with statutory regulations. The waqf property is eternal, in the sense that the benefits of the waqf property may be enjoyed, but the waqf property itself should not be isolated. The problem arises, what if the waqf property is no longer useful, it will be even more useful if the property is sequestered, for example, sold or changed its designation. Sayyid Sabiq stated, that if the waqf has occurred, then it cannot be sold, donated, and treated with something that eliminates the waqf. If the person who is waqf dies, then the waqf is not inherited, because this is what the Wakif wants and because of the words of the Messenger of Allah, peace be upon him. $^{24}$

In Act No. 41 of 2004 in essence is not much different from the Government Regulation no. 28 of 1977, it's just that the Law provides alternative dispute resolution through deliberation, mediation, arbitration, and the last resort through the courts, and basically the main way in resolving waqf disputes is by way of deliberation to reach consensus, as contained in article Article 62 of Act No. 41 of 2004, namely:

1) Settlement of waqf disputes can be reached through deliberation to reach consensus.

2) If the dispute resolution method as referred to in paragraph 1 is not successful, it can be resolved through mediation, arbitration, or court.

In resolving this waqf land dispute, the parties present included Wakif heirs, nadhir, religious leaders, community leaders and were also attended by several residents of the surrounding community. The result of this deliberation is that the mosque still functions as a place of worship. The deliberation between the two parties is a combination of a humanitarian approach with a security approach. Although both parties to the dispute (Nazhir and heirs of Wakif) both insist on their respective opinions, in the end this dispute problem can be resolved the stages of a good policy formulation process by going through various processes of consultation, confirmation and persuasion with various figures.

\section{Closing}

Implementation of the registration of the transfer of ownership of land due to waqf based on Ministerial Regulation no. 2 of 2017 in Madiun Regency, namely:

${ }^{24}$ Sayyid Sabiq, 1996, Fikih Sunah, Al-Maarif, Bandung p.156. 
a. For waqf land registration activities that have not been certified (customary land), namely PPAIW on behalf of Nazhir, he came to the Madiun Regency Land Office with an Application for Certification of Waqf Land that had been signed and had sufficient stamp duty and completed the required documents such as the Waqf Pledge Deed, photocopy of KTP/KK, Photocopy of KTP/identity of the right owner, certificate of land history, statement of physical control, power of attorney for application, photocopy of land and building tax, proof of title/proof of ownership, certificate of non-dispute and letter of approval of Nadzir. b. For the process of registering waqf land that has been certified, there are slight differences in the types of documents that must be completed.

5. References

Journal:

[1] Fatimah, Pendaftaran Tanah Wakaf Dalam Konteks Kepastian Hukum Hak Atas Tanah, Jurnal hukum samudra keadilan vol. 13 No. 2 JulyDecember 2018

Books:

[1] Abror, Khoirul, 2014, Dinamika Perwakafan Dalam Pemikiran Hukum Islam, Peraturan Perundang-Undangan Di Indonesia Dan NegaraNegara Muslim." Al-'Adalah

[2] Adrian Sutedi, 2012, Sertifikat Hak Atas Tanah, Sinar Grafika Jakarta

[3] Athoillah, 2014, Hukum Wakaf (Hukum Benda Bergerak dan Tidak Bergerak dalam Fikih dan Peraturan Perundang-Undangan di Indonesia), Yrama Widya, Bandung

[4] Boedi Harsono, 2007, Hukum Agraria Indonesia: Sejarah Pembentukan Undang-undang Pokok Agraria, Isi dan Pelaksanaannya, Cetakan ke-11, Djambatan, Jakarta

[5] Dr. Donna O. Setia budhi, 2012, Kewenangan Pemerintah dalam Pengaturan Penguasaan Tanah Negara, Kementrian Pendidikan dan Kebudayaan, Fakultas Hukum, Manado.

[6] Dyara, Radhite Oryza, 2018, Panduan Mengurus Tanah Rumah dan Perizinannya, Legality, Yogyakarta

[7] H. Moh Anwar, 1992, Muamalat, Munakahat, Faaid, dan Janayat, Rineka Cipta, Jakarta

[8] Muhammad Bakri, 2007, Hak Menguasai Tanah Oleh Negara (Paradigma Baru Untuk Reformasi Agraria), Citra Media, Yogyakarta

[9] Mukti Fajar dan Yulianto, 2010, Dualisme Penelitian Hukum Normatif dan Empiris, Pustaka Pelajar, Yogyakarta 
[10] Sayyid Sabiq, 1996, Fikih Sunah, Al-Maarif, Bandung

[11] Soerjono Soekanto dan Sri Mamadji, 2009, Penelitian Hukum Normatif: Suatu Tinjauan Singkat, Raja Grafindo Persada, Jakarta

[12] Sudirman Hasan, 2011, Wakaf Uang (persepektif Fiqih, Hukum Positif dan Manajemen), UIN Maliki Press, Malang

[13] Urip Santoso, 2007, Kepastian Hukum Wakaf Tanah Hak Milik, Kencana Prenada Media Group, Jakarta

[14] Wahbah Zuhaili, 2006, Al-Fiqh wa Adillatuhu, Juz VIII, Daar al-Fikr al-Mu'asir,Damaskus

[15] Yulfasni, 2010, Hukum Kontrak, Magister Kenotariatan Fakultas Hukum Universitas Andalas Padang

Regulations:

[1] Act No. 6 of 1997 concerning Land Registration Procedures Regarding Owned Land Waqf

[2] Regulation of the Minister of Agrarian Affairs and Spatial Planning/Head of the National Land Agency of the Republic of Indonesia Number 2 of 2017 concerning Procedures for Registration of Waqf Land

[3] Government Regulation Number 25 of 2018 concerning Amendments to Government Regulation Number 42 of 2006 concerning Implementation of Act No.41 of 2004 concerning Waqf 